\title{
Two Buddhisms Further Considered
}

\author{
Paul David Numrich \\ Loyola University Chicago, USA
}

\section{Introduction}

Over the past century and a half, many observers have recognized a 'two Buddhisms' dichotomy, framed in broad ethnic terms, that characterizes the Buddhist presence in the West. Two types of Buddhists pursue substantively different perspectives and practices of Buddhism - ethnic Asians born into a Buddhist cultural heritage, and non-Asian converts to Buddhism. Critical reflection on this two Buddhisms dichotomy dates only to the early 1990s, but since then it has exercised the field of contemporary Buddhist studies. This essay presents an analytical history and critical assessment of the two Buddhisms notion. I will recommend that advocates and critics alike acknowledge the value of the notion, and that they direct their energies toward advancing the field in creative ways, both within and outside the two Buddhisms paradigm.

First, a clarification of how the related concepts of ethnicity, race, and religion will be used in this essay (see Stout 1975; Burkey 1978; Smith 1978; Abramson 1980; Becker 1988; Conzen et al. 1992; Hammond and Warner 1993). Ethnicity, or ethnic group identity, is based on perceived shared origins and cultural characteristics, a collective sense of peoplehood and belonging, a mutual acknowledgement that 'we' and 'they' differ in substantive ways. Ethnic identity is socially constructed rather than primordial, dynamic rather than static, continually negotiated and reconfigured through interaction among dominant and minority groups in society. Ethnic identities are often created, enhanced, or submerged under larger categories through the migration process as groups find their place in a new society. In the case of ethno-racial groups, ethnic identity is linked primarily to physical characteristics; for ethno-religious groups, ethnic identity is linked primarily to religion. Particular ethnic-Asian Buddhist populations, such as Chinese, Japanese, or Vietnamese Buddhists, and the general category of ethnic-Asian Buddhists combine both racial and religious identifying characteristics. In the context of this essay, the term 'ethnic Asians' and its adjectival form 'ethnic-Asian' refer to Asian Buddhist minority populations in the West.

\section{Analytical history of the two Buddhisms notion}

The 'two Buddhisms' of ethnic Asians and non-Asian converts were recognized long before the term gained its current content in the early 1990s. Before the 
1990s, the notion typically functioned as an unexamined assumption about the societies in which Buddhists lived, and thus generated little descriptive or analytical reflection. Some scholars who acknowledged the existence of the two Buddhisms employed other typologies in discussing the Buddhist presence in the West.

In his study of Victorian-era Buddhism in the United States, originally published in 1992 as critical reflection on the two Buddhisms typology began, Thomas Tweed categorized Euro-American and Asian-American Buddhists as substantively different kinds of Buddhists, although he recognized mutual influences between the two types (2000, 34-9). This broad ethnic divide was historically embedded in social and legal structures that targeted the Asian 'strangers from a different shore' for discriminatory treatment (Takaki 1998). '[I]n response to the exclusionary impulse', writes historian of American religion Martin Marty, 'the Chinese and Japanese who were chiefly in California and elsewhere on the West Coast, developed cultural enclaves which made them seem only more remote and mysterious. Religion was a reinforcer of these enclaves and, since it was an alien religion to people with biblical heritages, it only served to increase the distance between peoples' (1986, 107; cf. Mann et al. 2001).

Chinese immigrants to the United States in the 1800s and early 1900 s, whose syncretistic folk religion included Buddhist elements, established temples often derisively labeled 'joss houses' ('joss' being a term imported from Asia, a corruption of the Portuguese word for god, deus). As Rick Fields notes, 'Caucasians rarely visited the joss houses, and then only as tourists at some of the more public temples in Chinatown' (1992, 75; cf. Sung 1967, 130-2). In some instances, Chinese temples hired a white superintendent 'in order to disarm any possible white critics of a strange, "heathen" place of worship' (Wells 1962, 20).

The Japanese community in the United States during the same period established a denominational structure for Jodo Shinshu Buddhism - initially called the Buddhist Mission of North America, later the Buddhist Churches of America - which has always maintained a primarily ethnic-Japanese identity (Ogura 1932; Tajima 1935; Radin 1946; Rust 1951; Horinouchi 1973; Kashima 1977; Tuck 1987). Contrasting the institutional role of the Buddhist temple in Japan and America, sociologist Tetsuden Kashima writes: 'In Japan, the temples in the community are viewed predominantly as religious organizations; in America, the [Buddhist Mission of North America temples] served as a place not only for religious solace, but also for social gatherings that preserved communal ethnic ties' (1977, 113-4). This resulted in a functional ethnic parallelism between Asian and non-Asian Buddhists, as Louise Hunter summarizes: 'There were some Caucasians in Hawaii and on the mainland who sympathized with the teachings of Buddhism and who had even, it was said, expressed an interest in the priesthood. But these haoles [whites], it was observed, did not feel at home in most Buddhist "churches." Architecture and religious artifacts which remained distinctly Oriental were thought to alienate Occidentals' (1971, 205-6). Initiatives to develop a non-ethnocentric form of 
Japanese Jodo Shinshu Buddhism in Hawaii in the 1920s and 1930s were eventually quashed by a bishop 'desirous of restricting Jodo Shinshu Buddhism to the Japanese' (Kashima 1977, 57). Subsequent calls for the Buddhist Churches of America to engage in active outreach to non-Japanese Americans have not garnered significant success (Kashima 1977, 208-9; Bloom 1990; 1998).

Mixed-ethnic exceptions proved the rule of ethnic parallelism during the early period of Buddhism in the United States. For instance, a group calling itself The Dharma Sangha of Buddha was formed in 1900 in San Francisco, and attracted as many as 20 Japanese and 25 non-Japanese members at its height (Fields 1992, 145). But ethnic parallelism generally prevailed, even under a single organization's roof, as in Nyogen Senzaki's zendos in San Francisco and Los Angeles in the early 1900s where Japanese and non-Japanese followers gathered on different nights (Fields 1992, 181), and in programming for interested whites provided by some Jodo Shinshu temples on the American mainland, such as the Three Treasures Society established in 1900 (Rust 1951, 143-5). Tellingly, the World's Parliament of Religions, held in Chicago in 1893, ignored the traditionalist Buddhism practiced by Chinese and Japanese immigrants in the United States in favor of a modernist Buddhism palatable to white intellectuals and a curious public enamored of 'Oriental' philosophies (Jackson 1981, 243-61). The contemporary ill-treatment of the immigrant Chinese and Japanese populations was broached at the Parliament (Barrows 1893, 88, 167-8, 444-50), but no serious attention was given to their brand of Buddhism.

A few observers prior to the 1990s reflected intentionally on the two Buddhisms dichotomy, if only minimally. Historian of religion Joseph Kitagawa distinguished 'Oriental' Buddhists, whom he considered 'ethnic religious groups' analogous to Scandinavian Lutherans, and non-Asians who found Buddhism intellectually attractive, depicting the latter unflatteringly in these words: '... Buddhism tends to attract those Caucasian-Americans who do not fit into their own society and religious tradition or those who try to use Buddhism for non-religious ends, etc. The last problem is especially acute in reference to Zen Buddhism, which has fascinated many young non-conformists in America' (Kitagawa 1967, 55). Kosho Yamamoto (1967), a Japanese traveler in the mid-1960s, simply noted the presence of immigrant Asian Buddhist populations while providing a detailed description of the 'new' Buddhists of Europe (i.e., European converts). Robert Ellwood's (1983) contribution to a special issue of the journal Concilium on new religious movements mentioned that followers of Asian religions in North America, including Buddhism, fell into two categories, 'immigrants and their descendants' and 'occidentals', each having a quite different 'temper'. In another publication, Ellwood summarized that 'North American Buddhism has long had two strands, ethnic and occidental', which have pursued different institutional trajectories 'despite occasional exchanges' (1987, 438). Around the same time, E. Allen Richardson focused his book, East Comes West, on immigrants in order to redress the imbalance of scholarly and media attention devoted to 'indigenous Caucasian devotees' of Buddhism and other Asian religions in North America (1985, xiii, 179, n. 1). 
Other observers prior to the 1990s acknowledged the existence of two Buddhisms broadly framed in ethnic terms but chose another categorization scheme in analyzing the Buddhist presence in the West. Throughout her seminal book, Buddhism in America, Emma Layman (1976) distinguished 'Orientals and non-Orientals' and 'American versus Asian Buddhists' (for example, 262-3) but, when drawing a portrait of America's Buddhists, she proposed a typology of 'three major styles', by which she seems to have meant distinctive aspects of Buddhist practice and organizational polity, an approach she found more helpful than a typology 'according to sect' (Layman 1976, 252): (1) 'evangelistic' (the Nichiren Shoshu/Soka Gakkai International movement), (2) 'meditational' (Zen and other groups that emphasize meditation practices), and (3) 'church' (the Buddhist Churches of America and other ethnic-Asian groups). In his overview of Buddhism in the West, Heinz Bechert (1984) explained how the large, early Asian emigration to the United States had created a different Buddhist presence there than in Europe - in effect, a two Buddhisms dichotomy — although Bechert did not employ this notion systematically in surveying the American Buddhist landscape. The same can be said of other surveys that implicitly or explicitly recognized ethnicity as a salient factor for Buddhist groupings in the West (for example, Leidecker 1957; Benz 1976; Rajavaramuni 1984).

The early 1990s marked a watershed in the evolution of the two Buddhisms notion. As we have seen in the foregoing overview, most pre-1990s observers recognized the substantive differences between ethnic-Asian and convert Buddhism yet engaged in minimal reflection about the implications of this dichotomy. Beginning in the 1970s, a great deal of scholarly attention was directed at convert Buddhism as a 'new religious movement', to the neglect of the ethnic-Asian wing of the two Buddhisms (Numrich 1996, xxi-xxii). This all changed in the wake of a controversy that placed the two Buddhisms dichotomy squarely at the center of scholarly and popular discourse about the Buddhist presence in the United States.

The controversy began with an editorial in the second issue (Winter 1991) of Tricycle, a periodical aimed at a convert Buddhist readership. Editor-in-chief Helen Tworkov (1991), reflecting on the emergence of what she labeled 'American Buddhism', made the following claim: 'The spokespeople for Buddhism in America have been, almost exclusively, educated members of the white middle class. Meanwhile, even with varying statistics, Asian-American Buddhists number at least one million, but so far they have not figured prominently in the development of something called American Buddhism'. This prompted a strong rebuttal from Ryo Imamura, a third-generation JapaneseAmerican Buddhist priest. In a letter to the editor, dated April 1992 but never published in Tricycle, Imamura objected to the fact that 'Tworkov has restricted "American Buddhism" to mean "white American Buddhism", Imamura rehearsed the historical struggles of Asian-American Buddhists in a racist society and their significant contributions to 'the growth of American Buddhism' despite the social forces arrayed against them. 'We Asian Buddhists have ... everything that white Buddhist centers have and perhaps more', Imamura asserted (in Prebish 1993, 190-1). 
This simmering controversy aired publicly in 1993 and 1994. Imamura's letter and a response by Tworkov were included in coverage by an obscure periodical called The Sangha Newsletter of the Wider Shin Buddhist Fellowship in the summer of 1994 (Nattier 1998, 191, n. 19). Tricycle's Fall 1994 issue featured the topic 'Dharma, Diversity and Race', with contributions by Rick Fields, Victor Sogen Hori, and others. Hori, a third-generation Japanese-Canadian Buddhist, distinguished the 'ethnic religion' of Asian Buddhists in North America from what he called the 'missionary religion' taught by Asian Buddhist teachers to non-Asian converts. 'While both groups claim to be Buddhist', Hori explained, 'each approaches Buddhism from quite a different starting point' $(1994,50)$. Rick Fields commented on the past, present, and future of America's two Buddhisms: 'Today the divergence between white American Buddhists and Asian-American Buddhists is as wide as or perhaps even wider than it was in the past. The Asian-American Buddhists are going one way, the white American Buddhists another. Looking at it this way, we see not one but two American Buddhisms' (1994, 56). Although Fields here invoked the notion of 'two Buddhisms', the distinction of coining the phrase falls to Charles Prebish, whose 1993 article 'Two Buddhisms Reconsidered' adapted his original usage of the phrase (Prebish 1979, 51) to the current controversy. In an intervening article, Prebish (1988) had drawn a clear distinction between 'two radically differing groups' - 'Asian immigrants' and 'Caucasian Americans' — but he did not yet apply the term 'two Buddhisms' to this distinction. Prebish made this application explicitly in his later article, distinguishing the two Buddhisms practiced by 'ethnic Asian-American Buddhist groups' and 'mostly members of Europeanderived ancestry' (1993, 189).

The controversy of the early 1990s made it difficult for anyone in scholarly or popular circles to avoid the two Buddhisms distinction. Among advocates and critics alike, the notion stimulated a creative new discourse about the Buddhist presence in Western societies. Many, if not most, observers now employ this dichotomy to identify the key category break in contemporary Buddhism, regardless of whether they invoke the actual phrase 'two Buddhisms' (for example, Croucher 1989; Baumann 1994; Prebish 1998; 1999, 57-63; 2000; 2001; Tanaka 1998; McLellan 1999; Williams and Queen 1999; Chai 2001; Clasquin 2002; Matthews 2002; McMahan 2002; Simmer-Brown 2002; Spuler 2002). Various labels for the two wings have been offered: ethnic Buddhism and new Buddhism (Coleman 2001), heritage Buddhists and new Buddhists (Nattier 2001), cradle Buddhists and convert Buddhists (Tweed 2000; 2002), culture Buddhists and convert Buddhists (Numrich 2000). Carl Bielefeldt (2001), who uses the labels hereditary Buddhists and convert Buddhists, writes: 'Whatever we call them, the distinction between the two types is striking'. Popular discussions influenced by scholars have also adopted the typology (for example, Religion Watch 1994; van Biema 1997; 'Tensions in American Buddhism' 2001; 'Ethnic vs. Convert Buddhism' Farrelly 2002). Although advocates of the two Buddhisms typology may forego extended critical reflection about it, they certainly have more awareness of its implications now than before the recent controversy. 
Some scholars modify or refine the basic two Buddhisms typology, or adopt it with caveats. Peter Gregory (2001) assigns only provisional value to the two Buddhisms approach. Gregory, who finds the field of American Buddhist studies hampered by a 'still primitive level of sophistication' in such matters (2001, 246), predicts that 'the meaningfulness of this distinction is likely to diminish with time as the boundaries separating the two "communities" inevitably change and blur'. For now, Gregory grants, the two Buddhisms typology offers 'an initial foothold in sorting out a phenomenon that otherwise threatens to overwhelm us with its complexity' (2001, 242-3). Richard Seager agrees about the provisional utility of such an approach. Like Gregory, Seager (2002, 118) believes that distinctions within contemporary Buddhism in the United States will inevitably fade away, and that 'an indigenous American form of the Dharma will emerge'. Seager (1999; 2002) proposes a 'three Buddhisms' typology, advocating a category break between long-established ('old-line') and recently arrived ethnic-Asian Buddhist populations, with converts as the third category. However, despite its convenience, simplicity, and 'a good deal of explanatory power' (Seager 2002, 116), even this typology has only limited value in Seager's mind: 'It is my own view that the idea that there are three American Buddhisms can be shelved, only to be brought out from time to time to gauge how issues articulated in a founding era are progressing' $(2002,118)$. As Seager and others point out, Buddhism's founding era in some Asian societies lasted several centuries - thus, it is still early in the West.

Typologically, Seager's three Buddhisms challenges the two Buddhisms' easy conflation of the experiences of ethnic Asians who arrived in the United States in different historical eras. Peter Gregory argues for retaining the two Buddhisms category break while still recognizing the 'major divide' that separates the historical cohorts within the ethnic-Asian category: 'Although the contemporary historical situation is entirely different from the prewar period, the difference between the two Buddhisms still seems to hold in a general way. Asian American and immigrant Buddhists tend to be Buddhist for different reasons than American convert Buddhists, and Buddhism plays a different role in their lives' $(2001,243,244)$. This line of discourse reminds us that the label 'immigrant' is appropriate for recent groups (Numrich 1996), but it is not comprehensive enough to account for the entire ethnic-Asian wing of the two Buddhisms typology since some Buddhist populations now extend beyond the third generation in the West.

Thomas Tweed's cumulative body of work argues for a basic two Buddhisms dichotomy of 'cradle Buddhists who inherited the faith and converts who chose it' (2002, 20; cf. 1999; 2000, xi-xxii), yet he pushes the underlying assumptions of such an approach. Tweed distinguishes 'adherents' and 'sympathizers' of Buddhism. Defining a Buddhist adherent, whether cradle or convert, is no simple task, Tweed argues, since adherence can be measured by a variety of standards, and religious identities are always hybrid complexities. Granting the importance of focusing on Buddhist adherents, Tweed suggests that scholars pay equal attention to the ways in which sympathizers contribute to the Buddhist presence in the West. 
Some scholars reject the basic two Buddhisms approach, on various grounds and to varying degrees. It has been dismissed altogether as too simplistically dichotomous to be of much use. 'Distinctions such as convert versus immigrant Buddhism or American versus Asian Buddhism necessarily gloss over [the] diversity' of Buddhist America, writes Donald Swearer (2001). One of Swearer's former students, Wendy Cadge (2001), argues that 'the current picture is considerably more complex' than a two Buddhisms dichotomy can portray. A bifurcated typology also cannot easily accommodate cases where the two types blend or interact, such as mixed-religious marriages (Perreira 2002) or mixedethnic institutions - unless, of course, these are seen as exceptions to the two Buddhisms rule. In at least two other examples of mixed-ethnic situations inter-Buddhist associations and the 'parallel congregations' found in many ethnic-Asian Buddhist temples - the two Buddhisms rule persists in intriguing ways. Most inter-Buddhist associations maintain and celebrate the ethnic diversity within their membership, which generally breaks out along two Buddhisms lines (cf. Numrich 1999). In the parallel congregations phenomenon, ethnic Asians and non-Asian converts practice their respective types of Buddhism under the same institutional roof and a shared clerical leadership (Numrich 1996; 2000).

Some lament that the two Buddhisms typology unnecessarily exacerbates the tensions sparked by the controversial Tricycle editorial, and thus should be abandoned for ethical reasons. As Peter Gregory puts it, the scholarly problem became a polarizing community problem for Buddhist America (2001, 246). However, as Kenneth Tanaka notes regarding this controversy, the two Buddhisms typology reflects a social reality that need not be contentious: 'While this division cannot be denied completely, perhaps, the reality is not as serious as reported. Certainly, no pervasive animosity is driving apart the two camps. The separation that we do witness is not due to any conscious effort to exclude the other but is more a natural tendency to gravitate to those with shared background and interests' (1998, 288).

Other scholars have proposed alternative typologies for the contemporary Buddhist presence in the United States and other Western societies. 'One approach that has gained some currency in recent years speaks of "two Buddhisms", Jan Nattier (1998, 188-9) wrote, 'the Buddhism of Asian Americans, on the one hand, and that of European Americans (sometimes labeled "White Buddhism") on the other'. But Nattier found this 'simple opposition ... clearly inadequate to the task, primarily because it fails to account for the full spectrum of racial and ethnic diversity in Buddhist America', such as ethnic Asians who meditate with white Buddhists or non-white Buddhist converts. 'To make sense of the landscape of Buddhist America', Nattier wrote elsewhere $(1997,74)$, 'one must go beyond race and ethnicity to consider an entirely different factor: the ways in which these various forms of American Buddhism were transmitted to the United States'. She thus proposed a tripartite typology of modes of transmission: Import, Export, and 'Baggage' Buddhism (Nattier 1995; 1997; 1998).

Among other contributions to the growing discourse about the two Buddhisms 
approach, Nattier's critique provided an important corrective to the lingering stereotype that convert Buddhism was a whites-only affair. She took seriously the adherents of Nichiren Shoshu/Soka Gakkai International Buddhism, who are largely non-white, who chant rather than meditate, and who, along with ethnic-Asian Buddhists, had been slighted by those sharing Helen Tworkov's vision of an emerging 'American Buddhism'. Still, Nattier's typology could be understood as a variation of the basic two Buddhisms dichotomy (Numrich 2000, 201, n. 6; Gregory 2001 246), with indigenous, non-Asian Buddhists converted through either Import and Export modes of transmission on one side, and 'Baggage' Buddhists, whom Nattier identifies as ethnic Asians 'born into the faith of their ancestors' $(1995,47)$, on the other. Judging by her most recent contribution (Nattier 2001), it appears that Nattier has returned to a two Buddhisms position, referring to 'two rather unusual groups' in contemporary American Buddhism, 'recent converts to Buddhism' and 'recent Asian immigrants', or 'new Buddhists' and 'heritage Buddhists'. As she put it in an earlier work, 'there is usually precious little contact between "ethnic" Buddhist groups in America, made up of recent immigrants to this country, and "elite" groups composed of relatively privileged, non-immigrant American converts. From a sociological standpoint it is hardly surprising that these two types of groups should have little in common, and that they should draw on quite distinct aspects of the Buddhist tradition' (Nattier 1992, 531, n. 5).

David Machacek (2001) does not reject the two Buddhisms approach per se, but argues that it tells only half the story, the demand side of what ethnic Asians and converts want from their respective Buddhisms. Machacek combines this with Nattier's typology, which he considers the supply side of the story, to offer 'a more compelling and useful way to think about Buddhism in America' (2001, 66). This results in four categories of Buddhism - Traditional, Ethnic, Convert, and Americanized - the first two emphasizing different aspects of the ethnoreligious identities of immigrant Buddhists, and the third representing the other wing of the standard two Buddhisms model. According to Machacek, the fourth category, Americanized Buddhism, 'represents the future of Buddhism in America ... [since] Buddhist organizations will be increasingly made up of American-born Buddhists, both the children of converts and the children of immigrants' (2001, 70). Machacek uses the Nichiren Shoshu/Soka Gakkai International (NS/SGI) movement as a case study for his model, contrasting it to the Buddhist Churches of America.

The NS/SGI case raises important considerations for the two Buddhisms approach. First, NS/SGI ostensibly poses a typological anomaly. Richard Seager, for instance, writes that SGI, the lay branch of the movement following a schism in the early 1990s, 'fits awkwardly in the convert camp' (2002, 113; cf. Gregory 2001, 246). James Coleman locates SGI 'somewhere between the ethnic Buddhism of the Asian immigrants and [the] three streams of the new Buddhism' examined in his book (Zen, Vajrayana, and Vipassana), and decides to bracket SGI out of his analysis of convert Buddhism altogether (2001, 9; cf. Coleman 1999, 92). This hesitance stems from NS/SGI's marked differences in perspectives, practices, and demographics when compared with the majority of 
Buddhist converts. Yet this ignores the obvious fact that most NS/SGI Buddhists in America are 'new' Buddhists, to use Coleman's term, who, like their convert counterparts in other groups, have experienced identity transformation by adopting a religious worldview different from that of their ethnic heritage and of the culture in which they were raised. Machacek classifies SGI as an immigrant group, yet his own scholarship indicates that it has provided only minimal ethno-religious functions for Japanese immigrants and that ethnic attachment is waning among American-born ethnic-Japanese members (Machacek and Mitchell 2000; Machacek 2001). My own sense is that NS/ SGI's sectarian Buddhist identity eclipsed its ethno-religious functions early on, especially in the United States where the movement quickly shifted its emphasis to convert recruitment. Thus, it properly belongs in the convert category, where it resided in the early literature on new religious movements and religious conversion dynamics (for example, Snow and Phillips 1980; Snow et al. 1980).

NS/SGI is the only convert-Buddhist group to raise a second generation in the faith. This presents another typological consideration for the two Buddhisms approach. '[S]hould children and grandchildren of convert Buddhists, if raised as Buddhists, be qualified as convert Buddhists without conversion?' asks Martin Baumann (2002b, 54; cf. Seager 2002, 106). The conscious choice of identity transformation is fundamental to the conversion phenomenon (Travisano 1970; Heirich 1977; Lofland and Skonovd 1981). Non-Asian Buddhist converts in Western societies adopt a religious worldview different from that of their ethnic heritage and of the mainstream culture in which they were raised. An argument can be made that the term 'convert' still applies to the children of the original cohort since this new generation must at some point consciously choose to perpetuate their parents' rejection of their former religious worldviews.

In the long term, however, a cultural heritage of Buddhist identity could be created for non-Asian converts if they became an ethno-religious subgroup within a larger population group, like the Amish or the Mormons within the white population of the United States, or African-American Muslims within the black population. In such a scenario, after several generations, Buddhism would serve the same cultural function for these groups as it does now for AsianAmerican Buddhists. Eventually, the term 'convert' would not apply to the descendants of the original cohort, since they would no longer be part of the religious mainstream and would inherit an ethnic Buddhist heritage instead of perpetuating their ancestors' rejection of their original ethnic heritage. NS/SGI may be the only convert group with the necessary intergenerational stability for this scenario to emerge. It remains to be seen whether any of the more individualistic, meditation-oriented convert groups will survive the baby boomer generation, or instead fade away as did convert Buddhism in Victorianera America (see Tweed 2000).

Of course, the whole notion of 'conversion' has been challenged by both critics and advocates of the two Buddhisms typology. The term seems too strong for individuals who find Buddhism attractive but do not consider themselves exclusive or even serious adherents of the religion (Coleman 2001, 
196; Gregory 2001, 242). For instance, many Jewish converts to Buddhism claim a dual identity, both Jewish and Buddhist (or 'JUBU') (Kamenetz 1994; Boorstein 1997). As Lionel Obadia explains in discussing Jewish Buddhists in Israel, 'Their approach to Buddhism is mainly characterized by rejection of the institutionalized forms of Judaism, not by withdrawal from their Jewishness. The incorporation of [Buddhist] practices and beliefs is not considered as a threat to their [Jewish] identity since they gave up the praxis of orthodox Judaism for a new definition of Jewishness' (2002, 185). Does this constitute 'conversion'? I would argue that it does, since it entails identity transformation and the adoption of a new religious worldview differing from that associated with their ethnic Jewish heritage. The retention of aspects of Jewish cultural identity does not negate the significance of the new religious identity, any more than in the cases of white or black Buddhist converts who retain certain social and cultural identifiers that continue to differentiate them from ethnic-Asian Buddhists, especially racial identity. Even in situations where Jewish rituals are combined with Buddhist practices in a new religious syncretism (Obadia 2002, 180), Buddhism functions as the primary religious interpretive filter for the participants. The same holds for Catholic Buddhists and Protestant Buddhists.

Unlike David Machacek, who combines Jan Nattier's modes of transmission typology and the two Buddhisms typology, Martin Baumann rejects both. With regard to the two Buddhisms, Baumann (2001, 2-3) proposes that '[a]ttention needs to be drawn to the contrast between traditionalist and modernist Buddhism that is prevalent in both Asian and non-Asian settings', traditionalist Buddhism comprising popular or folk religious practices, modernist Buddhism comprising a more cognitive emphasis on meditation, scriptures, and rationalism. Although Baumann suggests that a traditionalist/modernist dichotomy suffuses both camps, his descriptions make traditionalist Buddhism characteristic of Asian Buddhists and modernist Buddhism characteristic of non-Asian Buddhists (2001, 25-8, 30) — again, the basic two Buddhisms dichotomy framed along broad ethnic lines. In his contributions to Westward Dharma, Baumann (2002b) reiterates his rejection of the two Buddhisms dichotomy in one chapter, yet employs it in his discussion of Buddhism in Europe in another (Baumann 2002a).

Although I am not aware of any critics of the two Buddhisms typology who have articulated this as an alternative, categorizing Buddhists by 'denomination' has been common in the literature (Numrich 2000, 192; see earlier discussion). The three major branches of Buddhism are Theravada, Mahayana, and Vajrayana, each comprising numerous traditions and lineages, such as Pure Land and Zen within Mahayana. A case can be made that the two Buddhisms distinction often, if not usually overshadows shared denominational identity in Western contexts. Substantive differences in perspectives and practices can be found between the Vipassana meditation movement and immigrant Theravada Buddhism (Numrich 1996; Fronsdal 1998), between convert Vajrayana groups and ethnic Tibetans (Lavine 1998), and between white Zen Buddhists and their ethnic-Japanese counterparts (Asai and Williams 1999). A classic example of this ethnic parallelism is found in suburban Chicago, where white and ethnic- 
Vietnamese groups of Thich Nhat Hanh followers engage in different styles of Buddhist practice, unaware even of each other's existence (Numrich 2000, 196).

\section{Descriptive and analytical utility of a two Buddhisms typology framed in broad ethnic terms}

A major advantage of the two Buddhisms typology is its recognition of real differences in the historical appropriation of Buddhist identity. In the largest sense, one wing taps into a generations-old Buddhism bound up with cultural identities, and the other wing is creating a new religious identity without cultural precedents in its adherents' own ethnic histories. This simple dichotomy should not be dismissed as simplistic. As Janet McLellan describes the distinction in her discussion of Buddhism in Canada: 'The development of non-Asian Buddhism has had no historical links to western culture, government, power, or politics ... Among Asian Buddhists, the transmission of and belief in traditional doctrines and scriptures are expressed as part of their cultural heritage' (1999, 26-7). This difference in cultural 'rootage' helps to explain why ethnic-Asian Buddhism is expressed in community and family contexts, whereas convert Buddhism is typically individualistic (Ellwood 1983, 17; Tanaka 1998; Coleman 2001, 197-8; Gregory 2001, 244-5).

A related advantage of a two Buddhisms approach is that it highlights important majority/minority ethnic dynamics. Prior to the controversy of the early 1990s, most observers under-appreciated the implications of the social fact of two Buddhisms in Western societies. Some still do not fully appreciate the importance of this dichotomy. In two pointed essays stemming from the controversy, 'Confessions of a White Buddhist' (Fields 1994) and 'Divided Dharma: White Buddhists, Ethnic Buddhists, and Racism' (Fields 1998), Rick Fields identified racism as a key factor in what he called 'the dual development of American Buddhism' (1998, 196). As a 'white Buddhist' himself, Fields understood the privileged status that he and others like him enjoyed in a racially stratified society, and he wished to shed 'some light on the racism (unconscious though it may be) that makes up one many-braided strand of American society and so of American Buddhism'. 'What's more', Fields continued, 'those whom I have described as "white Buddhists" immediately recognize themselves in the description'. Fields admitted the inadequacy of the term 'white Buddhists' (1998, 196-8), but his point was well taken - ethnic identities and racial dynamics have mattered greatly in the history of Buddhism in the United States. Minority social status leads to a telling designation often employed by ethnicAsian Buddhists when referring to non-Asian Buddhist converts. As I put it in my description of two US temples, 'many if not most of the Asians in our temples are American citizens, and yet they commonly refer to the non-Asian members of the temples as "Americans", (Numrich 1996, 64).

Much has been written about the structural impediments to acceptance of Asian Americans as 'full Americans' in US society (Lowe 1996; Takaki 1998; Tuan 1998), and the field of Asian-American studies has recently underscored the crucial roles played by race, racism, and religion in minority group identity 
formation for Asian Americans (for example, Min and Kim 2002). David Yoo (2000, 123) points out that the Nisei or US-born second generation that matured in the 1920s-1940s had to confront the hard reality that 'Japanese Americans remained a marked population wherever they went'. Race and religion intersected for Japanese Americans, both Buddhists and Christians, and their temples and churches became institutions of minority ethnic identity in a repressive society (55-6, 120-1). As R. Stephen Warner observes, given America's racially stratified social structure, 'For the foreseeable future, they [Asian Americans] will continue to need their churches [and temples] as a refuge against lack of racial acceptance by the host society ... as well as a staging ground for attempts to overcome racism ...' (2001: 41).

The dialogue that occurs on such communal 'staging grounds' taps into deep historical and cultural linkages between homeland Asian and diasporic ethnicAsian identities. It is instructive to consider the terminology employed by Asian-Americans in discussing their religious identities: 'reconfiguring', 'return', 're-site-ing/reciting', 'retrieval', 'reexamination', 'reformulation', 'reconstructing', 'reappropriation', and 'revitalization' ('Critical Reflections on Asian American Religious Identity' 1996). The prefix 're-' in all of these terms has past, present, and future connotations, in that Asian-American groups draw from traditional heritages in adapting to new social contexts. As one of the participants in the discussion just cited summarized, 'All of these essays share the assumption of loss and separation from a parent tradition'. Moreover, all participate in the dilemma of '[h]ow to negotiate the shedding of culture without the loss of religious and, necessarily, ethnic identity' (187).

This challenge of ethnic identity formation devolves heavily on young immigrants and the generations of ethnic Asians born in racially stratified Western countries. The growing literature on the Korean-American experience explores the dynamics of ethnic identity formation in the second generation of that recent immigrant community. Despite significant second-generation disaffection from the Old World ways of their parents, a common theme in American immigration history generally (Hansen 1937; 1940), KoreanAmericans tend to retain an ethnic-Korean, or at least bicultural, identity (Cha 2001; Goette 2001; cf. Min and Kim 1999). As Fenggang Yang (2002, 91) notes in his contribution to Religions in Asian America, the reality of American racism eventually catches up to American-born Chinese, sending them back to ethnic-Chinese or pan-Asian Christian churches. In the same volume, Russell Jeung $(2002,239)$ examines the relatively small number of pan-Asian churches, explaining that they 'mobilize around racial boundaries'. Jeung generalizes that 'race continues to play a significant role in the lives of Asian Americans and their faith development' (2002, 240). Jung Ha Kim (2002, 205, 206) points out that although second-generation, pan-Asian churches may not be 'ethnic' in the same ways as their parents' churches, they nevertheless become 'reethnicized' with a racialized religious identity.

During recent field research in ethnic-Asian Buddhist temples for two projects in Chicago, we encountered a number of individuals who have re-appropriated a Buddhist identity within the ethnic-Asian context of their 
communities. Some older immigrants claimed to practice a traditional religiosity more intensely than they did in their home country, a common report in the literature (for example, Williams 1988; Kurien 2002). Some young ethnic-Asian Buddhists expressed a strong reformist or modernist attitude, as in the case of one young adult leader in the Vietnamese Buddhist Youth Association in the United States, an organization with four regional branches across the country. He told us that there is a difference between the Buddhist practices of many of his peers and those of their immigrant parents. Their parents merely 'believe' in Buddhism, he claimed, whereas he and others of his generation have come to 'know' Buddhism more accurately. Their parents practice the traditions they were taught in Vietnam, which include a lot of 'superstition' and elements not found in the teachings of the Buddha. The young people, on the contrary, have found the 'correct practices' of Buddhism.

Martin Baumann's earlier suggestion, that a traditionalist/modernist dichotomy is more salient than a two Buddhisms dichotomy framed in ethnic terms, deserves further consideration in this context. In one place, Baumann predicts that "communities within traditionalist Buddhism in the West [i.e., ethnic-Asian Buddhists] sooner or later will make moves toward a modernist Buddhism, a step held unavoidable to reach the youth and next generation' (2002b). As in the case of the young Vietnamese man just described, we already see evidence of a traditionalist/modernist debate in ethnic-Asian Buddhist communities, a carryover from developments in Asia during the past two centuries. Although modernist sentiments among ethnic-Asian Buddhists share some similarities with the modernist Buddhism found in non-Asian convert circles, I would argue that the ethno-religious context of Asian Buddhism makes a categorical difference. When ethnic-Asian Buddhists move from a traditionalist to a modernist interpretation of Buddhism, or even when they simply debate the two interpretations among themselves, they do so in the context of their ethnic-Asian identity, an identity reinforced by racial boundaries in Western societies.

Many scholars of Buddhism in Asia have made distinctions analogous to Baumann's traditionalist/modernist categories. Comparative sociologists point out the differences between popular religion and elite religion in all classdivided societies, including Buddhist Asia (Sharot 2001). Anthropologists have long spoken of little and great traditions in Asian Buddhism, a notion that retains its utility despite falling out of favor in some circles (Scott 1994; Sharot 2001, 14). Scholars of Asian Buddhism have documented the reformist and revivalist Buddhist movements that arose in response to Western colonialist pressures, creating a kind of 'Protestant Buddhism' critical of traditionalist Buddhism (Bond 1988; Gombrich and Obeyesekere 1988). The term 'Buddhist modernism' stems largely from the work of Heinz Bechert, who provides this succinct description: "[M] odern Buddhists rediscovered "original" Buddhism as a system of philosophical thought with the sole aim of showing a way to salvation from suffering and rebirth. Traditional cosmology, the belief in miracles, and other elements which were unacceptable to a modern thinker were now identified as inessential accretions or modifications of Buddhism 
accumulated during its long historical development ... [M] odernists describe Buddhism as "the religion of reason"...' (Bechert 1984, 275-6; cf. Sharf 1995).

Ethnic-Asian Buddhist groups in the West participate in long-standing communal dialogues about the meaning and practice of Buddhism primarily within a context of ethno-religious group identity. I first encountered the dialogue about traditionalist/modernist interpretations of Buddhism among ethnic-Asian Buddhists around the issue of god worship while conducting field work at Thai and Sri Lankan temples in the United States (Numrich 1996, 84-5). Recently, my research teams encountered this internal dialogue in several visits to a temple in Chicago that serves Southeast Asians.

During our initial visit, the abbot expressed concern about the Western scholarly view of Buddhism. He handed us a book entitled Buddhism: A Layman's Guide to Life, a compendium of ethical duties taken from the Pali scriptures and meant to help individuals reach Nirvana 'by the overcoming of evil which arise[s] through one's selfish desire, the cultivation of good through beneficial and helpful actions to one's fellow beings, and the purification of mind through insight into the true nature of things'. The abbot apologized that his temple is 'not a true representation of the Buddhist religion' and that its ritual services are more of a cultural experience than a religious one. On our next visit we made specific inquiries about traditionalist folk healing practices at his temple since we had heard from other sources that its resident monks regularly dispense herbal remedies. The abbot responded by distancing his temple from all such folk healing practices, which he finds inconsistent with what he called a 'purified' Buddhism that emphasizes the philosophical and ethical aspects of Buddhism, especially the importance of meditation for mind/body health. When temple members request an astrological consultation, a common element in popular traditionalist Buddhism in Southeast Asia, he said he discusses the matter with them, but he stressed to us that astrological readings, fortune telling, and the like would be irrelevant to 'purified' Buddhists.

Despite the abbot's preference for 'purified Buddhism', an interview of a female temple member uncovered the full range of popular healing practices carried on in his temple. Members receive astrological readings, amulets, and magical rituals from the monks, even though, in her judgment, 'the Buddha did not support such things'. If members were more 'mindful' and self-confident through meditative practices, she explained, they would not need popular supernatural aids. The sentiments expressed by this woman and the abbot typify the modernist Buddhist critique of traditionalist Buddhism, both in Asia and in ethnic-Asian Buddhist communities in the West. The small number of nonAsian converts who frequent this Chicago temple are unaware of this internal communal dialogue, receiving only the 'purified', modernist Buddhism promoted by the abbot. Indeed, alternative healing practices among Buddhists in the United States generally appear to follow the category break of the two Buddhisms (Numrich forthcoming).

The interesting case of Asian-Indian Buddhists in South Africa clarifies the category break in the two Buddhisms typology. As Michel Clasquin (2002) 
explains, the Buddhists of South Africa can be divided broadly into ethnicAsian Buddhist populations (Burmese, Chinese, and Indian) and Western Buddhists (overwhelmingly white). Although in one sense the Asian-Indian Buddhists could be seen as 'converts' from low-caste Hinduism, Clasquin nevertheless places them in the ethnic-Asian Buddhist category because 'one factor that caused them to adopt Buddhism as an alternative to Hinduism was that, unlike Christianity or Islam, Buddhism was at least of Indian origin' (2002). Clasquin concludes: 'Calling their religion an "ethnic Buddhism" is therefore not too far off the mark' (2002, 153). Their new Buddhist identity differs sociologically from Western convert Buddhism in South Africa. For ethnic Asians in the West, it is really not a matter of 'conversion' to Buddhism, even if one's family or ethnic group was not Buddhist in Asia in recent times. It is rather a matter of reversion, or of revisioning their Buddhist heritage, even if that heritage has suffered hiatus for some time, or has to be created in response to the social pressures involved in minority group identity formation (cf. Chandler 1998 on the Chinese in America).

\section{Recommendations to the field of contemporary Buddhist studies}

A two Buddhisms typology framed in broad ethnic terms captures an indisputable category break in the experiences, perspectives, and practices of contemporary Buddhist groups in the United States and other Western societies. The explicit recognition, since the early 1990s, of the significance of two Buddhisms, rather than one, has begun to redress earlier scholarly and popular neglect of ethnic-Asian Buddhism in favor of the convert phenomenon. The present category break between the two Buddhisms will remain as long as ethnic-Asian Buddhist groups hold minority status within the racialized social structures of Western societies (cf. Emerson and Smith 2000). Rick Fields knew that his fellow white convert Buddhists would recognize his description of their shared identity and privileged social status. Ethnic-Asian Buddhists likewise recognize their shared identity and minority social status. And both groups recognize the social chasm between them. I recall the Asian-American Buddhist who thanked me for a talk I gave about ethnic-Asian Buddhism to a virtually all-white audience at the Smithsonian Institution in Washington, DC: 'You described so well the Buddhism I was raised in', he said, with some emotion. For most of my audience that day, which included many Buddhist converts, the Asian-American Buddhist experience was as foreign as Asia itself.

Once scholars acknowledge the validity of the basic two Buddhisms distinction, they can turn their collective attention toward advancing the field of contemporary Buddhist studies in creative ways. Some recommendations follow.

Despite the attention it has received in the past decade, the potential of the two Buddhisms typology has not yet been exhausted. Although recent overviews of contemporary Buddhism in the West pay significant attention to ethnic-Asian Buddhists (Prebish and Tanaka 1998; Prebish 1999; Seager 1999; Williams and Queen 1999; Prebish and Baumann 2002), a vestigial preference 
to tell the convert story remains in scholarly and popular circles. To date we do not have a comprehensive study of ethnic-Asian Buddhism in North America, a gap I hope to begin to fill with a proposed volume of essays examining ethnic-Asian Buddhists in several North American cities. Large topics like the commonalities and differences between 'old-line' and recent ethnic-Asian Buddhist cohorts, immigrant versus refugee variables, inter-generational dynamics, denominational and ecumenical issues, and the effects of racism and minority social status need investigation. More comparative studies of Christians and Buddhists within a single ethnic-Asian population can be mounted (for example, Chai 2001). More work is also needed on particular ethnic-Asian Buddhist populations and groupings (see Kashima 1977; van Esterick 1992; Numrich 1996), both at the congregational level (for example, Padgett 2002; Perreira 2002) and broader (for example, Cadge 2002). Insights from multiple fields, especially Asian Buddhist studies, ethnic-Asian studies, American religious history, and recent immigrant religions, can help to place ethnic-Asian Buddhism in larger contexts than has heretofore typified contemporary Buddhist studies. For instance, the influences of post-colonial dynamics in Asia (for example, Bond 1988; Gombrich and Obeyesekere 1988) and current transnational religious networks (for example, Ebaugh and Chafetz 2002) on ethnic-Asian Buddhist communities in the West should be examined. To take another example, much can be learned about immigrant Buddhism by comparing and contrasting it with other immigrant religions. Has there been a Buddhist 'denominational' evolution comparable with that among mainstream religions in the United States (Herberg 1956; Niebuhr 1957)? What does a later generation's 'return' to ethnic identity mean for ethnic-Asian Buddhists, and how does it compare/contrast to this classic notion from immigration history (Hansen 1937; 1940)?

Much work remains to be carried out on the convert wing of the two Buddhisms typology as well. The significant extant scholarship on the two subgroupings within convert Buddhism - meditation groups (for example, Preston 1988; Coleman 2001) and the NS/SGI movement (for example, Hammond and Machecek 1999; Machacek and Wilson 2000) — needs to be collated and advanced in comprehensive fashion. What commonalities can be found among adherents in all convert groups, and what social and religious variables predispose individuals to pursue one kind of practice over others? The reputed eclecticism of convert Buddhists needs empirical substantiation - there may be more loyalty to specific traditions and lineages than we have been led to believe by anecdotal reports and philosophical dispositions toward an inevitable, singular 'American' or 'Western' Buddhism. Generational distinctions deserve investigation, along at least two comparative lines: (1) parents and children in the NS/SGI movement, and (2) baby boomer and later generations of non-Asian converts in general (see Loundon 2001).

Of course, the relationship between the two Buddhisms offers a great deal of grist for the research mill. Building on the work of Thomas Tweed (2000), historical comparisons between different eras can be drawn, examining both perennial tensions and benign mutual influences between the two camps. 
Activity along and across the borderline between the two types of Buddhism can be fascinating, for instance, in mixed-ethnic temples and groups, or dialogues among Buddhist leaders. Are there any examples of true 'fusion' of the two Buddhisms; that is, a completely new type of Buddhism forged out of elements taken equally from each side? This would differ from the 'assimilationist' ideal that sparked the two Buddhisms controversy in the early 1990s; namely, that all Buddhists should conform to 'white Buddhism' (cf. Numrich 1999).

As Richard Seager has pointed out to me, typologies create their own anomalies, exceptions, and blind spots. All of these should be examined thoroughly with regard to the two Buddhisms typology. The fluidity of the categories should be honored, as Thomas Tweed's insights on 'adherents' and 'sympathizers' suggest. Previous critiques of the two Buddhisms typology should be revisited, regardless of whether they still represent viable alternative typologies, such as Jan Nattier's notion of transmission modes and Martin Baumann's distinction between traditionalist and modernist Buddhism. The denominational typology should be considered on its own merits, divorced from its implications vis-à-vis the two Buddhisms typology, since it clearly represents another set of category breaks in the Buddhist presence in Western societies. Category breaks of gender and clergy/lay statuses should also be pursued. With regard to gender, we need more research that includes both converts and ethnic Asians (for example, Simmer-Brown 2002; Tsomo 2002). As to the clergy/laity topic, conventional wisdom says that lay expressions of Buddhism will eventually predominate in the United States, yet monastics, ordained teachers, and various kinds of specialists and trained leaders abound - what do these mean to the evolution of Buddhism here (Numrich 1998; Prebish 1999, 173-202)?

And we need creative new typologies. It is not helpful to criticize current typological efforts without offering viable alternatives. We gain little analytical return by merely acknowledging the existence of many discrete entities in a diverse universe without making meaningful statements about overarching themes and dynamics.

As I have suggested elsewhere, a dichotomy analogous to the two Buddhisms exists within other religions in the United States, and presumably elsewhere in the West (Numrich 2000; Mann et al. 2001; cf. Tweed 1997). Insights from the two Buddhisms discourse can be applied to the 'two Hinduisms', the 'two Sikhisms', and the 'two Islams' as well. One intriguing difference in the Muslim context in the United States is that most indigenous converts have not come from the dominant group in society (whites), but rather from a racial minority (blacks). How have the respective 'dual developments' (to use Rick Fields' term) of Buddhism and Islam differed because of this difference in racial composition?

\section{Note}

Earlier versions of this essay were presented at the annual meetings of the American Academy of Religion, Midwest Region, Chicago, IL, April 2002, and the Society for the Scientific Study of Religion, Salt Lake City, UT, November 2002. The author wishes to 
thank Richard Seager for his insightful recommendations regarding the purpose and tone of this essay.

\section{References}

Abramson, Harold J. 1980. 'Religion', in Stephen Thernstrom (ed), Harvard Encyclopedia of American Ethnic Groups, Cambridge, MA: Belknap Press, pp. 869-75.

Asai, Senryo and Duncan Ryuken Williams. 1999. 'Japanese American Zen Temples: Cultural Identity and Economics', in Duncan Ryuken Williams and Christopher S. Queen (eds), American Buddhism: Methods and Findings in Recent Scholarship, London: Curzon Press, pp. 20-35.

Barrows, John Henry (ed). 1893. The World's Parliament of Religions, 2 vols., Chicago, IL: The Parliament Publishing Company.

Baumann, Martin. 1994. 'The Transplantation of Buddhism to Germany: Processive Modes and Strategies of Adaptation', Method and Theory in the Study of Religion, 6, $35-61$.

Baumann, Martin. 2001. 'Global Buddhism: Developmental Periods, Regional Histories, and a New Analytical Perspective', Journal of Global Buddhism, 2, 1-43.

Baumann, Martin. 2002a. 'Buddhism in Europe: Past, Present, Prospects,' in Charles S. Prebish and Martin Baumann (eds), Westward Dharma: Buddhism Beyond Asia, Berkeley, CA: University of California Press, pp. 85-105.

Baumann, Martin. 2002b. 'Protective Amulets and Awareness Techniques, or How to Make Sense of Buddhism in the West', in Charles S. Prebish and Martin Baumann (eds), Westward Dharma: Buddhism Beyond Asia, Berkeley, CA: University of California Press, pp. 51-65.

Bechert, Heinz. 1984. 'Buddhist Revival in East and West', in Heinz Bechert and Richard Gombrich (eds), The World of Buddhism: Buddhist Monks and Nuns in Society and Culture, New York: Facts on File, pp. 273-85.

Becker, Laura L. 1988. 'Ethnicity and Religion', in Charles H. Lippy and Peter W. Williams (eds), Encyclopedia of the American Religious Experience: Studies of Traditions and Movements, New York: Scribner's, pp. 1477-91.

Benz, Ernst. 1976. 'Buddhism in the Western World', in Heinrich Dumoulin and John C. Maraldo (eds), Buddhism in the Modern World, New York: Collier Books, pp. 305-22.

Bielefeldt, Carl. 2001. At 'Tensions in American Buddhism', Religion and Ethics Newsweekly, 6 July, cover story [http://www.pbs.org/wnet/religionandethics/week445/ buddhism.html].

Bloom, Alfred. 1990. 'The Unfolding of the Lotus: A Survey of Recent Developments in Shin Buddhism in the West', Buddhist-Christian Studies, 10, 157-64.

Bloom, Alfred. 1998. 'Shin Buddhism in America: A Social Perspective', in Charles S. Prebish and Kenneth K. Tanaka (eds), The Faces of Buddhism in America, Berkeley, CA: University of California Press, pp. 32-47.

Bond, George D. 1988. The Buddhist Revival in Sri Lanka: Religious Tradition, Reinterpretation and Response, Columbia, SC: University of South Carolina Press.

Boorstein, Sylvia. 1997. That's Funny, You Don't Look Buddhist: On Being a Faithful Jew and a Passionate Buddhist, New York: Harper.

Burkey, Richard M. 1978. Ethnic and Racial Groups: The Dynamics of Dominance, Menlo Park, CA: Cummings.

Cadge, Gwendolyn A. 2001. 'Tensions in American Buddhism', Religion and Ethics Newsweekly, 6 July, cover story [http://www.pbs.org/wnet/religionandethics/week445/ buddhism.html].

Cadge, Gwendolyn A. 2002. 'Seeking the Heart: The First Generation Practices Theravada Buddhism in America', Ph.D. dissertation, Princeton University, NJ. 
Cha, Peter T. 2001. 'Ethnic Identity Formation and Participation in Immigrant Churches: Second-Generation Korean American Experiences', in Ho-Youn Kwon, Kwang Chung Kim and R. Stephen Warner (eds), Korean Americans and Their Religions: Pilgrims and Missionaries from a Different Shore, University Park, PA: Pennsylvania State University Press, pp. 141-56.

Chai, Karen J. 2001. 'Intra-Ethnic Religious Diversity: Korean Buddhists and Protestants in Greater Boston', in Ho-Youn Kwon, Kwang Chung Kim and R. Stephen Warner (eds), Korean Americans and Their Religions: Pilgrims and Missionaries from a Different Shore, University Park, PA: Pennsylvania State University Press, pp. 27394.

Chandler, Stuart. 1998. 'Chinese Buddhism in America: Identity and Practice', in Charles S. Prebish and Kenneth K. Tanaka (eds), The Faces of Buddhism in America, Berkeley, CA: University of California Press, pp. 14-30.

Clasquin, Michel. 2002. 'Buddhism in South Africa', in Charles S. Prebish and Martin Baumann (eds), Westward Dharma: Buddhism Beyond Asia, Berkeley, CA: University of California Press, pp. 152-62.

Coleman, James William. 1999. 'The New Buddhism: Some Empirical Findings', in Duncan Ryuken Williams and Christopher S. Queen (eds), American Buddhism: Methods and Findings in Recent Scholarship, London: Curzon Press, pp. 91-9.

Coleman, James William. 2001. The New Buddhism: The Western Transformation of an Ancient Tradition, New York: Oxford University Press.

Conzen, Kathleen Neils, David A. Gerber, Ewa Morawska, George E. Pozzetta and Rudolph J. Vecoli. 1992. 'The Invention of Ethnicity: A Perspective from the USA', Journal of American Ethnic History, 12, 3-41.

'Critical Reflections on Asian American Religious Identity'. 1996. Amerasia Journal, 22, 161-95.

Croucher, Paul. 1989. Buddhism in Australia 1848-1988, New South Wales University Press.

Ebaugh, Helen Rose and Janet Saltzman Chafetz (eds). 2002. Religion across Borders: Transnational Immigrant Networks, Walnut Creek, CA: Alta Mira Press.

Ellwood, Robert. 1983. 'Asian Religions in North America', Concilium: Religion in the Eighties, 161, 17-22.

Ellwood, Robert. 1987. 'Buddhism in the West', in Mircea Eliade (ed), Encyclopedia of Religion, vol. 2, New York: Macmillan Publishing Company, pp. 436-9.

Emerson, Michael and Christian Smith. 2000. Divided by Faith: Evangelical Religion and the Problem of Race in America, New York: Oxford University Press.

Farrelly, Maura Jane, 'Ethnic vs. Convert Buddhism'. 2002. Voice of America News, 15 December 2002 [http://www.voanews.com/article.cfm?objectid = E6619D30-BCC044A1-B4672A3B89B65E73\&title $=$ Ethnic \% 20vs \% 2E \% 20Convert \% 20Buddhism $\& \mathrm{db}=$ current].

Fields, Rick. 1992. How the Swans Came to the Lake: A Narrative History of Buddhism in America, 3rd edn, Boulder, CO and Boston, MA: Shambhala.

Fields, Rick. 1994. 'Confessions of a White Buddhist', Tricycle: The Buddhist Review, 4, 54-6.

Fields, Rick. 1998. 'Divided Dharma: White Buddhists, Ethnic Buddhists, and Racism', in Charles S. Prebish and Kenneth K. Tanaka (eds), The Faces of Buddhism in America, Berkeley, CA: University of California Press, pp. 196-206.

Fronsdal, Gil. 1998. 'Insight Meditation in the United States: Life, Liberty, and the Pursuit of Happiness', in Charles S. Prebish and Kenneth K. Tanaka (eds), The Faces of Buddhism in America, Berkeley, CA: University of California Press, pp. 164-80.

Goette, Robert D. 2001. 'The Transformation of a First-Generation Church into a Bilingual Second-Generation Church', in Ho-Youn Kwon, Kwang Chung Kim and R. Stephen Warner (eds), Korean Americans and Their Religions: Pilgrims and Missionaries from a Different Shore, University Park, PA: Pennsylvania State University Press, pp. 125-40. 
Gombrich, Richard and Gananath Obeyesekere. 1988. Buddhism Transformed: Religious Change in Sri Lanka, Princeton, NJ: Princeton University Press.

Gregory, Peter N. 2001. 'Describing the Elephant: Buddhism in America', Religion and American Culture: A Journal of Interpretation, 11, 233-63.

Hammond, Phillip and David Machacek. 1999. Soka Gakkai in America: Accommodation and Conversion, Oxford: Oxford University Press.

Hammond, Phillip E. and Kee Warner. 1993. 'Religion and Ethnicity in Late-TwentiethCentury America', Annals of the American Academy of Political and Social Science, 527, 55-66.

Hansen, Marcus Lee. 1937. The Problem of the Third Generation Immigrant, Augustana College Library Occasional Paper 16, Rock Island, IL: Swenson Swedish Immigration Research Center and Augustana College Library, 1987.

Hansen, Marcus Lee. 1940. The Immigrant in American History, Arthur M. Schlesinger (ed), Cambridge, MA: Harvard University Press.

Heirich, Max. 1977. 'Change of Heart: A Test of Some Widely Held Theories about Religious Conversion', American Sociological Review, 83, 653-80.

Herberg, Will. 1956. Protestant-Catholic-Jew: An Essay in American Religious Sociology, Garden City, NY: Doubleday.

Hori, Victor Sogen. 1994. 'Sweet-and-Sour Buddhism', Tricycle: The Buddhist Review, 4, 48-52.

Horinouchi, Isao. 1973. 'Americanized Buddhism: A Sociological Analysis of a Protestantized Japanese Religion', Ph.D. dissertation, University of California, Davis, CA.

Hunter, Louise H. 1971. Buddhism in Hawaii: Its Impact on a Yankee Community, Honolulu, HI: University of Hawaii Press.

Jackson, Carl T. 1981. The Oriental Religions and American Thought: NineteenthCentury Explorations, Westport, CT: Greenwood Press.

Jeung, Russell. 2002. 'Asian American Pan-Ethnic Formation and Congregational Culture', in Pyong Gap Min and Jung Ha Kim (eds), Religions in Asia America: Building Faith Communities, Walnut Creek, CA: Alta Mira Press, pp. 215-43.

Kamenetz, Rodger. 1994. The Jew in the Lotus, San Francisco, CA: Harper.

Kashima, Tetsuden. 1977. Buddhism in America: The Social Organization of an Ethnic Religious Institution, Westport, CT: Greenwood Press.

Kim, Jung Ha. 2002. 'Cartography of Korean American Protestant Faith Communities in the United States', in Pyong Gap Min and Jung Ha Kim (eds), Religions in Asia America: Building Faith Communities, Walnut Creek, CA: Alta Mira Press, pp. 185213.

Kitagawa, Joseph M. 1967. 'Buddhism in America, with Special Reference to Zen', Japanese Religions, 5, 32-57.

Kurien, Prema. 2002. "We Are Better Hindus Here": Religion and Ethnicity among Indian Americans', in Pyong Gap Min and Jung Ha Kim (eds), Religions in Asia America: Building Faith Communities, Walnut Creek, CA: Alta Mira Press, pp. 99120.

Lavine, Amy. 1998. 'Tibetan Buddhism in America: The Development of American Vajrayana', in Charles S. Prebish and Kenneth K. Tanaka (eds), The Faces of Buddhism in America, Berkeley, CA: University of California Press, pp. 100-15.

Layman, Emma McCloy. 1976. Buddhism in America, Chicago, IL: Nelson-Hall.

Leidecker, Kurt F. 1957. 'The Impact of Buddhism on the West', Journal of the Siam Society, 45(2), 1-27.

Lofland, John and Norman Skonovd. 1981. 'Conversion Motifs', Journal for the Scientific Study of Religion, 20(4), 373-85.

Loundon, Sumi (ed). 2001. Blue Jean Buddha: Voices of Young Buddhists, Boston, MA: Wisdom Publications.

Lowe, L. 1996. Immigrant Acts, Durham, NC: Duke University Press.

Machacek, David W. 2001. 'Immigrant Buddhism in America: A Model of Religious Change', Nova Religio, 5, 64-84. 
Machacek, David and Kerry Mitchell. 2000. 'Immigrant Buddhists in America', in David Machacek and Bryan Wilson (eds), Global Citizens: The Soka Gakkai Buddhist Movement in the World, Oxford: Oxford University Press, pp. 259-79.

Machacek, David, and Bryan Wilson (eds). 2000. Global Citizens: The Soka Gakkai Buddhist Movement in the World, Oxford: Oxford University Press.

Mann, Gurinder Singh, Paul David Numrich and Raymond B. Williams. 2001. Buddhists, Hindus, and Sikhs in America, New York: Oxford University Press.

Marty, Martin E. 1986. Modern American Religion, Volume 1: The Irony of It All, 1893-1919, Chicago, IL: University of Chicago Press.

Matthews, Bruce. 2002. 'Buddhism in Canada', in Charles S. Prebish and Martin Baumann (eds), Westward Dharma: Buddhism Beyond Asia, Berkeley, CA: University of California Press, pp. 120-38.

McLellan, Janet. 1999. Many Petals of the Lotus: Five Asian Buddhist Communities in Toronto, Toronto: University of Toronto Press.

McMahan, David L. 2002. 'Repackaging Zen for the West', in Charles S. Prebish and Martin Baumann (eds), Westward Dharma: Buddhism Beyond Asia, Berkeley, CA: University of California Press, pp. 218-29.

Min, Pyong Gap. 2002. 'A Literature Review with a Focus on Major Themes', in Pyong Gap Min and Jung Ha Kim (eds), Religions in Asia America: Building Faith Communities, Walnut Creek, CA: Alta Mira Press, pp. 15-36.

Min, Pyong Gap and Rose Kim (eds). 1999. Struggle for Ethnic Identity: Narratives by Asian American Professionals, Walnut Creek, CA: Alta Mira Press.

Min, Pyong Gap and Rose Kim (eds). 2002. Religions in Asia America: Building Faith Communities, Walnut Creek, CA: Alta Mira Press.

Nattier, Jan. 1992. 'Review Essay: History, Subjectivity, and the Study of Buddhism', Journal of the American Academy of Religion, 60(3), 525-36.

Nattier, Jan. 1995. 'Visible and Invisible: Jan Nattier on the Politics of Representation in Buddhist America', Tricycle: The Buddhist Review, 5, 42-9.

Nattier, Jan. 1997. 'Buddhism Comes to Main Street', Wilson Quarterly, Spring, 72-80.

Nattier, Jan. 1998. 'Who Is a Buddhist? Charting the Landscape of Buddhist America', in Charles S. Prebish and Kenneth K. Tanaka (eds), The Faces of Buddhism in America, Berkeley, CA: University of California Press, pp. 183-95.

Nattier, Jan. 2001. At 'Tensions in American Buddhism', Religion and Ethics Newsweekly, 6 July, cover story [http://www.pbs.org/wnet/religionandethics/week445/ buddhism.html].

Niebuhr, H. Richard. 1957. The Social Sources of Denominationalism, New York: Henry Holt.

Numrich, Paul David. 1996. Old Wisdom in the New World: Americanization in Two Immigrant Theravada Buddhist Temples, Knoxville, TN: University of Tennessee Press.

Numrich, Paul David. 1998. 'Theravada Buddhism in America: Prospects for the Sangha', in Charles S. Prebish and Kenneth K. Tanaka (eds), The Faces of Buddhism in America, Berkeley, CA: University of California Press, pp. 148-61.

Numrich, Paul David. 1999. 'Local Inter-Buddhist Associations in North America', in Duncan Ryuken Williams and Christopher S. Queen (eds), American Buddhism: Methods and Findings in Recent Scholarship, London: Curzon Press, pp. 117-42.

Numrich, Paul David. 2000. 'How the Swans Came to Lake Michigan: The Social Organization of Buddhist Chicago', Journal for the Scientific Study of Religion, 39(2), 189-203.

Numrich, Paul David. Forthcoming. 'Complementary and Alternative Medicine in America's "Two Buddhisms", in Linda Barnes and Susan Sered (eds), Religious Healing in America, New York: Oxford University Press.

Obadia, Lionel. 2002. 'Buddha in the Promised Land: Outlines of the Buddhist Settlement in Israel', in Charles S. Prebish and Martin Baumann (eds), Westward Dharma: Buddhism Beyond Asia, Berkeley, CA: University of California Press, pp. 177-88. 
Ogura, Kosei. 1932. 'A Sociological Study of the Buddhist Churches in North America with a Case Study of Gardena, California', Master's dissertation, University of Southern California.

Padgett, Douglas M. 2002. 'The Translating Temple: Diasporic Buddhism in Florida', in Charles S. Prebish and Martin Baumann (eds), Westward Dharma: Buddhism Beyond Asia, Berkeley, CA: University of California Press, pp. 201-17.

Perreira, Todd LeRoy. 2002. 'Sasana Sakon and the New Asian American: Intermarriage and Identity at a Thai Buddhist Temple in Silicon Valley', unpublished manuscript.

Prebish, Charles S. 1979. American Buddhism, North Scituate, MA: Duxbury Press.

Prebish, Charles S. 1988. 'Buddhism', in Charles H. Lippy and Peter W. Williams (eds), Encyclopedia of the American Religious Experience: Studies of Traditions and Movements, vol. 2, New York: Charles Scribner's Sons, pp. 669-82.

Prebish, Charles S. 1993. 'Two Buddhisms Reconsidered', Buddhist Studies Review, 10(2), 187-206.

Prebish, Charles S. 1998. 'Introduction', in Charles S. Prebish and Kenneth K. Tanaka (eds), The Faces of Buddhism in America, Berkeley, CA: University of California Press, pp. 1-10.

Prebish, Charles S. 1999. Luminous Passage: The Practice and Study of Buddhism in America, Berkeley, CA: University of California Press.

Prebish, Charles S. 2000. 'Buddhism', in Wade Clark Roof (ed), Contemporary American Religion, vol. 1, New York: Macmillan Reference USA, pp. 87-90.

Prebish, Charles S. 2001. 'Tensions in American Buddhism', Religion and Ethics Newsweekly, 6 July, cover story [http://www.pbs.org/wnet/religionandethics/week445/ buddhism.html].

Prebish, Charles S. and Martin Baumann (eds). 2002. Westward Dharma: Buddhism Beyond Asia, Berkeley, CA: University of California Press.

Prebish, Charles S. and Kenneth K.Tanaka (eds). 1998. The Faces of Buddhism in America, Berkeley, CA: University of California Press.

Preston, David L. 1988. The Social Organization of Zen Practice: Constructing Transcultural Realities, New York: Cambridge University Press.

Radin, Paul. 1946. 'Japanese Ceremonies and Festivals in California', Southwestern Journal of Anthropology, 2(2), 152-79.

Rajavaramuni, Phra. 1984. Thai Buddhism in the Buddhist World: A Survey of the Buddhist Situation against a Historical Background, Bangkok: Amarin Printing Group.

Religion Watch (1994) A Newsletter Monitoring Trends in Contemporary Religion, 9(9), July/August.

Richardson, E. Allen. 1985. East Comes West: Asian Religions and Cultures in North America, New York: Pilgrim Press.

Rust, William Charles. 1951. 'The Shin Sect of Buddhism in America: Its Antecedents, Beliefs, and Present Condition', Ph.D. dissertation, University of Southern California.

Scott, David. 1994. Formations of Ritual: Colonial and Anthropological Discourses on the Sinhala Yaktovil, Minneapolis, MN: University of Minnesota Press.

Seager, Richard Hughes. 1999. Buddhism in America, New York: Columbia University Press.

Seager, Richard Hughes. 2002. 'American Buddhism in the Making', in Charles S. Prebish and Martin Baumann (eds), Westward Dharma: Buddhism Beyond Asia, Berkeley, CA: University of California Press, pp. 106-19.

Sharf, Robert H. 1995. 'Buddhist Modernism and the Rhetoric of Meditative Experience', Numen, 42, 228-83.

Sharot, Stephen. 2001. A Comparative Sociology of World Religions: Virtuosos, Priests, and Popular Religion, New York: New York University Press.

Simmer-Brown, Judith. 2002. 'The Roar of the Lioness: Women's Dharma in the West', in Charles S. Prebish and Martin Baumann (eds), Westward Dharma: Buddhism Beyond Asia, Berkeley, CA: University of California Press, pp. 309-23. 
Smith, Timothy L. 1978. 'Religion and Ethnicity in America', American Historical Review, 83, 1155-85.

Snow, David A. and Cynthia L. Phillips. 1980. 'The Lofland-Stark Conversion Model: A Critical Reassessment', Social Problems, 27(4), 430-47.

Snow, David A., Louis Zurcher and Sheldon Ekland-Olson. 1980. 'Social Networks and Social Movements', Sociological Review, 45(5), 787-801.

Spuler, Michelle. 2002. 'The Development of Buddhism in Australia and New Zealand', in Charles S. Prebish and Martin Baumann (eds), Westward Dharma: Buddhism Beyond Asia, Berkeley, CA: University of California Press, pp. 139-51.

Stout, Harry S. 1975. 'Ethnicity: The Vital Center of Religion in America', Ethnicity, 2(2), 204-24.

Sung, Betty Lee. 1967. The Story of the Chinese in America, New York: Macmillan.

Swearer, Donald. 2001. 'Tensions in American Buddhism', Religion and Ethics Newsweekly, 6 July, cover story [http://www.pbs.org/wnet/religionandethics/week445/ buddhism.html].

Tajima, Paul J. 1935. 'Japanese Buddhism in Hawaii: Its Background, Origin, and Adaptation to Local Conditions', Master's dissertation, University of Hawaii.

Takaki, Ronald. 1998. Strangers from a Different Shore: A History of Asian Americans, updated and revised edn, Boston, MA: Little, Brown and Company.

Tanaka, Kenneth K. 1998. 'Epilogue: The Colors and Contours of American Buddhism', in Charles S. Prebish and Kenneth K. Tanaka (eds), The Faces of Buddhism in America, Berkeley, CA: University of California Press, pp. 287-98.

'Tensions in American Buddhism'. 2001. Religion and Ethics Newsweekly, 6 July, cover story [http://www.pbs.org/wnet/religionandethics/week445/cover.html].

Travisano, Richard. 1970. 'Alternation and Conversion as Qualitatively Different Transformations', in G.P. Stone and H. Farberman (eds), Social Psychology through Symbolic Interaction, Waltham, MA: Ginn-Blaisdell, pp. 594-606.

Tsomo, Karma Lekshe. 2002. 'Buddhist Nuns: Changes and Challenges', in Charles S. Prebish and Martin Baumann (eds), Westward Dharma: Buddhism Beyond Asia, Berkeley, CA: University of California Press, pp. 255-74.

Tuan, M. 1998. Forever Foreigners or Honorary Whites? The Asian Ethnic Experience Today, New Brunswick, NJ: Rutgers University Press.

Tuck, Donald R. 1987. Buddhist Churches of America - Jodo Shinshu, Lewiston, NY: Edwin Mellen.

Tweed, Thomas A. 1997. 'Asian Religions in the United States: Reflections on An Emerging Subfield', in Walter H. Conser, Jr. and Sumner B. Twiss (eds), Religious Diversity and American Religious History: Studies in Traditions and Cultures, Athens, GA: University of Georgia Press, pp. 189-217.

Tweed, Thomas A. 1999. 'Night-Stand Buddhists and Other Creatures: Sympathizers, Adherents, and the Study of Religion', in Duncan Ryuken Williams and Christopher S. Queen (eds), American Buddhism: Methods and Findings in Recent Scholarship, London: Curzon Press, pp. 71-90.

Tweed, Thomas A. 2000. The American Encounter with Buddhism, 1844-1912: Victorian Culture and the Limits of Dissent, Chapel Hill, NC: University of North Carolina Press.

Tweed, Thomas A. 2002. 'Who Is a Buddhist? Night-Stand Buddhists and Other Creatures', in Charles S. Prebish and Martin Baumann (eds), Westward Dharma: Buddhism Beyond Asia, Berkeley, CA: University of California Press, pp. 17-33.

Tworkov, Helen. 1991. 'Many Is More', Tricycle: The Buddhist Review, 1(2), 4. van Biema, David. 1997. 'Buddhism in America', Time, 13 October, 72-81.

van Esterick, Penny. 1992. Taking Refuge: Lao Buddhism in North America, Arizona State University Program for Southeast Asian Studies.

Warner, R. Stephen. 2001. 'The Korean Immigrant Church as Case and Model', in Ho-Youn Kwon, Kwang Chung Kim and R. Stephen Warner (eds), Korean Americans and Their Religions: Pilgrims and Missionaries from a Different Shore, University Park, PA: Pennsylvania State University Press, pp. 25-52. 
Wells, Mariann Kaye. 1962. 'Chinese Temples in California', Master's dissertation, University of California, Berkeley, CA.

Williams, Raymond Brady. 1988. Religions of Immigrants from India and Pakistan: New Threads in the American Tapestry, New York: Cambridge University Press.

Williams, Duncan Ryuken and Christopher S. Queen (eds). 1999. American Buddhism: Methods and Findings in Recent Scholarship, London: Curzon Press.

Yamamoto, Kosho. 1967. Buddhism in Europe: Report of a Journey to the West, in 1966, of an Eastern Buddhist, Tokyo: The Karinbunko.

Yang, Fenggang. 2002. 'Religious Diversity among the Chinese in America', in Pyong Gap Min and Jung Ha Kim (eds), Religions in Asia America: Building Faith Communities, Walnut Creek, CA: Alta Mira Press, pp. 71-98.

Yoo, David K. 2000. Growing Up Nisei: Race, Generation, and Culture among Japanese Americans of California, 1924-1949, Urbana, IL: University of Illinois Press.

Correspondence address: Paul David Numrich, Loyola University Chicago, $6525 \mathrm{~N}$. Sheridan Road, Chicago IL 60626, USA. pnumric@luc.edu 